\title{
O potrzebie przywrócenia właściwego statusu Radzie do spraw Bezpieczeństwa Jądrowego i Ochrony Radiologicznej²
}

Wpłynął: 28.04.2020. Zaakceptowany: 24.04.2021

\section{Streszczenie}

Artykuł podejmuje problematykę funkcjonowania jednego z organów doradczych centralnych organów administracji rządowej, tj. Rady do spraw Bezpieczeństwa Jądrowego i Ochrony Radiologicznej działającej przy Prezesie Państwowej Agencji Atomistyki, naczelnym organie dozoru jądrowego w Polsce, właściwym w sprawach bezpieczeństwa jądrowego i ochrony radiologicznej określonym ustawą Pr. atm. Artykuł przedstawia założenia funkcjonowania Rady jako organu doradczego organu dozoru jądrowego w oparciu o prawo międzynarodowe i europejskie oraz poglądy doktryny prawa energii jądrowej. Ważną rolę w odniesieniu do Rady spełniają akty soft law, w szczególności tzw. standardy bezpieczeństwa Międzynarodowej Agencji Energii Atomowej (IAEA safety standards). Mimo że nie mają mocy wiążącej, stanowią wartościowy i obszerny zbiór zaleceń wspomagających działalność prawodawczą na poziomie regionalnym i krajowym. Celem opracowania jest również krytyczna analiza nowelizacji Prawa atomowego (Pr. atm.) z 2016 r. w części odnoszącej się do zmian przeprowadzonych w zakresie sposobu kształtowania składu Rady.

Słowa kluczowe: prawo atomowe, prawo energii jądrowej, Rada ds. Bezpieczeństwa Jądrowego i Ochrony Radiologicznej, Prezes Państwowej Agencji Atomistyki, organy dozoru jądrowego, centralne organy administracji rządowej, organy doradcze.

1 Dr Tomasz R. Nowacki-Akademia Pomorska (Polska); e-mail: tomasz.nowacki@klimat.gov.pl; ORCID: 0000-0002-6684-8384.

2 Badania nie są finansowane przez żadną instytucję. 


\title{
TOMASZ R. NOWACKI
}

\section{On the Need for Restoring the Proper Status of the Council for Nuclear Safety and Radiation Protection Affairs ${ }^{3}$}

\begin{abstract}
The article covers the issue of the functioning of one of the advisory bodies of central governmental administration, i.e. the Council for Nuclear Safety and Radiation Protection Affairs, which is associated with the President of the National Atomism Agency (PAA), the chief nuclear supervision body in Poland, which is the competent authority in nuclear safety and radiation protection affairs, as defined in the Atomic Law (Prawo atomowe). The article presents the objectives of the functioning of the Council as an advisory body to the nuclear supervision authority on the basis of international and European law and the views of the nuclear energy law doctrine. In relation to the Council, an important role is played by soft law acts, especially the so-called IAEA safety standards. Despite the fact that they are not legally binding, they constitute a valuable and extensive collection of recommendations supporting regional and national legislative activity. The purpose of this study is also a critical analysis of the amendment to the Atomic Law from 2016 in the section relating to changes made to the way of shaping the Council's make-up.
\end{abstract}

Keywords: Atomic Law, nuclear energy law, Council for Nuclear Safety and Radiation Protection Affairs, President of the National Atomism Agency, nuclear supervision bodies, central governmental administration, advisory bodies.

3 The research has not been supported financially by any institution. 


\section{Wstęp}

W dniu 10 września 2016 r. weszła w życie ustawa z dnia 6 lipca 2016 r. o zmianie ustawy - Prawo atomowe ${ }^{4}$. Ustawa m.in. zmieniła zasady kształtowania składu Rady do spraw Bezpieczeństwa Jądrowego i Ochrony Radiologicznej (Rada), która jest organem opiniodawczo-doradczym Prezesa Państwowej Agencji Atomistyki (Prezes PAA), negatywnie ingerując w jej pozycję ustrojową. Ustawodawca zadecydował o odebraniu Prezesowi PAA kompetencji do kształtowania składu Rady, przekazując je nadzorującemu Prezesa PAA ministrowi oraz wprowadził możliwość dyskrecjonalnego odwołania jej członków przed upływem kadencji przez tegoż ministra. W konsekwencji Rada, wbrew pierwotnym założeniom oraz międzynarodowym standardom, przestała być niezależnym organem doradczym Prezesa PAA. Niniejszy artykuł stanowi krytyczną analizę dokonanej zmiany oraz postuluje przywrócenie Radzie należnego jej statusu, a więc tego sprzed nowelizacji Pr. atm. z 2016 r., czego efektem, zdaniem autora, będzie wzmocnienie systemu bezpieczeństwa jądrowego i ochrony radiologicznej w Polsce.

\section{Istota funkcjonowania Rady}

Rada nie była, jak dotąd, samodzielnym przedmiotem zainteresowania doktryny prawa energii jądrowej lub też prawa administracyjnego w ogólności. Pewne odniesienia do niej znajdują się jedynie w publikacjach na temat struktury organów odpowiedzialnych za nadzór nad bezpieczeństwem wykorzystywania energii jądrowej oraz rozwój energetyki jądrowej w Polsce ${ }^{5}$. Tym bardziej warto przybliżyć założenia

$4 \quad$ Dz. U. poz. 1343.

5 Zob. m.in. T.R. Nowacki, Ograniczenie autonomii Prezesa Państwowej Agencji Atomistyki, „Przegląd Sejmowy" 2018, 4, s. 59-60, 66-69; idem, Prawne gwarancje niezależności dozoru jądrowego w Polsce, [w:] I. Ramus (red.), Obrót powszechny i gospodarczy. Problemy publicznoprawne i ekonomiczne, Kielce 2014, s. 302-303; W. Dworak, Podstawy instytucjonalne konieczne do rozwoju energetyki jądrowej w Polsce, , Rocznik Nauk Prawnych" 2014, 2, s. 176; J.G. Firlus, K. Michalak, Realizacja inwestycji w zakresie budowy obiektu jądrowego w Polsce - wybrane zagadnienia, „Przegląd Prawa Publicznego” 2015, 9, s. 105. Nie można też pominąć jedynej publikacji w całości odnoszącej się do Rady. Choć nie jest to publikacja prawnicza oraz obarczona jest pewnymi niedociągnięciami merytorycznymi, nie można jej odmówić, choćby częściowo, waloru poznawczego. Zob. G. Tokarz, Rada do spraw bezpieczeństwa jądrowego i ochrony radiologicznej-geneza, usytuowanie, działalność, Praca ta została opublikowana kilkakrotnie w monografiach 
leżące u podstaw koncepcji organów doradczych organów dozoru jądrowego, a także choćby w zarysie postarać się spojrzeć na Radę przez pryzmat krajowego, polskiego prawa administracyjnego jako na organ doradczy centralnego organu administracji rządowej.

Organy doradcze organów dozoru jądrowego istnieją od początków regulacji sektora energii i energetyki jądrowej. Przez lata zmieniał się ich charakter i zakres spraw jakimi się zajmowały. Początkowo ich aktywność dotyczyła głównie kwestii związanych z promocją rozwoju technik jądrowych ze szczególnym uwzględnieniem energetyki. Z czasem, wraz z wyodrębnieniem organów odpowiedzialnych wyłącznie za regulację $\mathrm{w}$ dziedzinie bezpieczeństwa jądrowego i ochrony radiologicznej, wyodrębniały się także specyficzne organy doradcze, których zakres działania ograniczał się do kwestii bezpieczeństwa. Trendy zarówno w tym zakresie, jak i w regulacji jądrowej sensu largo, wyznaczano w USA, państwie z największą liczbą budowanych elektrowni jądrowych, a co za tym idzie - z największą liczbą wyzwań prawnych i regulacyjnych. To tam w 1974 r. powstał pierwszy niezależny organ dozoru jądrowego - Jądrowa Komisja Regulacyjna (Nuclear Regulatory Commission - NRC) z rozbudowanym systemem ciał doradczych i konsultacyjnych. Z uwagi na swą przydatność, mocną pozycję USA jako eksportera technologii reaktorowych oraz siłę polityczną w systemie Organizacji Narodów Zjednoczonych (ONZ), koncepcje amerykańskie trafiały z czasem do aktów prawnych i dokumentów Międzynarodowej Agencji Energii Atomowej (MAEA), a za ich pośrednictwem (bądź bezpośrednio w przypadku importu technologii i regulacji) także do porządków krajowych poszczególnych państw ${ }^{6}$.

Rola ciał doradczych w postaci rad, komitetów, paneli, zespołów polega na dostarczaniu tzw. „drugiej opinii” organom dozoru jądrowego dotyczącej różnych aspektów ich działań. Zadaniem organów doradczych jest m.in. opiniowanie

oraz prasie branżowej. Dla porządku podaję wszystkie miejsca publikacji: [w:] Bezpieczeństwo energetyczne: rynki surowców i energii: energetyka w czasach politycznej niestabilności. Bezpieczeństwo, gospodarka, ochrona środowiska, polityka, technologia, zarządzanie, red. P. Kwiatkiewicz, R. Szczerbowski, Poznań 2015, s. 677-684; [w:] R. Szczerbowski (red.), Energetyka węglowa i jądrowa: wybrane aspekty, Poznań 2017, s. 234-244; [w:] R. Maciejewski (red,), Cyberbezpieczeństwo i bezpieczeństwo fizyczne obiektów w energetyce: wybrane aspekty badawcze, Poznań 2018, s. 306-316. Materiał opublikowano także pod innym tytułem, zob. Bezpieczeństwo jądrowe i ochrona radiologiczna. Nie tylko PAA..., „Energia Gigawat” 2016, 1, 26-30 oraz na stronach internetowych Centrum Informacji o Rynku Energii, https://www.cire.pl/pliki/2/tokarzgrzegorzradaenergetykijadrowej.pdf (dostęp: 28.03.2020).

6 O rozwoju regulacji jądrowej w perspektywie historycznej zob. J.S. Walker, T.R. Wellock., A Short History of Nuclear Regulation 1946-2009, Washington 2010 wraz z podaną tam dalszą literaturą. To syntetyczne opracowanie dotyczy wprawdzie Stanów Zjednoczonych, ale większość z koncepcji rozwijanych w USA jako rezultat transferu amerykańskich technologii reaktorowych oraz za pośrednictwem MAEA trafiała do innych państw wykorzystujących energię, w tym energetykę, jądrową. 
projektów dokumentów i aktów, w tym zezwoleń, wydawanych przez regulatora7 . Fachowa opinia wydawana przez specjalistów z zewnątrz podnosi wartość merytoryczną procesu decyzyjnego, gdyż zmniejsza ryzyko niewłaściwych rozstrzygnięć. Rodzaj organu, jego kształt, zadania oraz inne warunki funkcjonowania zależą od specyfiki systemu prawa i administrowania w danym państwie. W odniesieniu do organów doradzających organom dozoru jądrowego można jednak wyróżnić kilka cech wspólnych. Przede wszystkim są to najczęściej podmioty złożone ze specjalistów pochodzących spoza urzędów obsługujących organ regulacyjny. Umożliwia to bezstronne spojrzenie na projekty decyzji, bądź innych aktów i dokumentów regulatora, co nie byłoby możliwe, a w najlepszym przypadku bardzo utrudnione, przy udziale personelu zaangażowanego uprzednio w przygotowanie aktu lub dokumentu względnie powiązanego relacjami służbowymi bądź towarzyskimi z osobami, które przygotowały projekt rozstrzygnięcia, aktu prawnego, dokumentu itd. Drugą wspólną cechą jest wymóg eksperckości członków takiego gremium, którzy powinni być uznanymi specjalistami z dziedzin niezbędnych dla poprawnej oceny przedkładanych projektów. Trzecią wspólną cechą jest wymóg niezależności ciał doradczych, analogiczny jak ma to miejsce w odniesieniu do samego organu regulacyjnego. Obowiązek zagwarantowania jego niezależności od podmiotów wykorzystujących i promujących energię jądrową wynika z wiążących przepisów prawa międzynarodowego ${ }^{8}$, a w przypadku członków Europejskiej Wspólnoty Energii Atomowej (EWEA), będących równocześnie członkami Unii Europejskiej, także europejskiego ${ }^{9}$. Członkowie gremiów doradczych organów regulacyjnych nie mogą być związani z podmiotami, wobec których wydawane są rozstrzygnięcia, oraz powinni mieć zagwarantowaną swobodę wypowiedzi,

7 Zob. C. Stoiber, A. Cherf, W. Tonhauser, M. de Loudres Vez Carmona, Handbook on Nuclear Law. Implementing Legislation, Vienna 2010, s. 32.

8 Konwencja bezpieczeństwa jądrowego sporządzona w Wiedniu 20 września 1994 r. (Dz. U. z 1997 r., $\mathrm{Nr} 42$, poz. 262); Wspólna konwencja bezpieczeństwa w postępowaniu z wypalonym paliwem jądrowym i bezpieczeństwa w postępowaniu z odpadami promieniotwórczymi sporządzona w Wiedniu 5 września 1997 r. (Dz. U. z 2002 r., Nr 202, poz. 1704); Konwencja o ochronie fizycznej materiałów jądrowych sporządzona w Wiedniu i otwarta do podpisu 3 marca 1980 r. w Wiedniu i Nowym Jorku (Dz. U. z 1989 r., Nr 17, poz. 93) w wersji zmienionej Poprawką z 2005 r. (Dz. U. z 2006 r., Nr 235, poz. 1696).

9 Dyrektywy Rady: 2009/71/Euratom z dnia 25 czerwca 2009 r. ustanawiająca wspólnotowe ramy bezpieczeństwa jądrowego obiektów jądrowych (Dz. Urz. UE L 172 z 2.7.2009, s. 18, Dz. Urz. UE L 260 z 3.10.2009, s. 40 oraz Dz. Urz. UE L 219 z 25.7.2014, s. 42), 2011/70/Euratom z dnia 19 lipca 2011 r. ustanawiająca ramy wspólnotowe $\mathrm{w}$ zakresie odpowiedzialnego i bezpiecznego gospodarowania wypalonym paliwem i jądrowym i odpadami promieniotwórczymi (Dz. Urz. UE L 199 z 2.8.2011, s. 48), 2013/59/Euratom z dnia 5 grudnia 2013 r. ustanawiająca podstawowe normy bezpieczeństwa w celu ochrony przed zagrożeniami wynikającymi z narażenia na działanie promieniowania jonizującego oraz uchylającej dyrektywy 89/618/Euratom, 90/641/Euratom, 96/29/Euratom, 97/43/Euratom i 2003/122/ Euratom (Dz. Urz. UE L 13 z 17.1.2014, s. 1). 
co najłatwiej zrealizować poprzez wprowadzenie wymogu kadencyjności obwarowanej zamkniętym, wąskim katalogiem przyczyn odwołania członka przed upływem kadencji ${ }^{10}$.

Wiążące prawo międzynarodowe dotyczące regulacji energii jądrowej odnosi się wprost jedynie do samych organów dozoru jądrowego, w tym do konieczności zagwarantowania ich niezależności, pozostawiając kwestie organów doradczych instrumentom soft law. Najważniejszymi z nich są standardy bezpieczeństwa MAEA posiadające status prawa stanowionego przez organizację międzynarodową. Mimo upoważnienia do ich przyjmowania w umowie konstytuującej tę organizację, tj. w Statucie MAEA (art. III.A.6.) ${ }^{11}$, standardy bezpieczeństwa, poza kilkoma określonymi przypadkami, nie mają mocy wiążącej w odniesieniu do podmiotów prawa międzynarodowego innych niż sama MAEA. Nie oznacza to wszakże, że są one pozbawione skutków prawnych. Przede wszystkim jednak standardy MAEA posiadają dużą doniosłość praktyczną, stanowiąc zbiór wzorcowych rozwiązań gotowych do zastosowania w drodze dobrowolnej implementacji. Postępowanie takie jest udziałem wielu państw. Standardy stanowią dla nich wartościową merytorycznie pomoc w postaci niezbędnej wiedzy eksperckiej, wpływając tym samym na wewnętrzne procesy prawotwórcze. Uzasadnieniem dla ich przyjmowania przez MAEA jest m.in. fakt, iż tworzenie przez społeczność międzynarodową wiążących ram prawnych (w praktyce wielostronnych umów międzynarodowych) $\mathrm{w}$ zakresie objętym standardami, $\mathrm{z}$ jednej strony nie nadąża za postępem technicznym, z drugiej jest wymagające politycznie. Z uwagi na wysoką wartość merytoryczną oraz normatywny charakter standardy bezpieczeństwa nadają się zarówno do implementacji do krajowych porządków prawnych, jak i do transformacji w umowy międzynarodowe, bądź inne akty prawne, jak np. dyrektywy EWEA. Tym samym, nawet mimo braku wiążącego charakteru, standardy bezpieczeństwa MAEA są istotną częścią prawnomiędzynarodowego reżimu energii jądrowej $^{12}$. W polskim porządku prawnym istnieje obowiązek brania pod uwagę

10 Więcej o zasadzie niezależności organów dozoru jądrowego zob. T.R. Nowacki, Niezależność organów dozoru jądrowego. Próba rekonstrukcji zakresu pojęciowego, [w:] K. Jeleń, Z. Rau (red.), Energetyka jądrowa $w$ Polsce, Warszawa 2012, s. 580-622.

11 Statut Międzynarodowej Agencji Energii Atomowej podpisany w Nowym Jorku dnia 26 października 1956 r. (Dz. U. z 1958 r. Nr 41, poz. 187 ze zm.).

12 Więcej o standardach bezpieczeństwa MAEA, w tym o ich strukturze, hierarchii oraz miejscu w systemie źródeł prawa, zob. T.R. Nowacki, Możliwość uznania standardów bezpieczeństwa Międzynarodowej Agencji Energii Atomowej za źródło prawa w świetle Konstytucji Rzeczypospolitej Polskiej, [w:] H. Babiuch, P. Kapusta, J. Michalska (red.), Aktualne problemy konstytucji. Księga jubileuszowa z okazji 40-lecia pracy naukowej Profesora Bogustawa Banaszaka, Legnica 2017, s. 639-659. Zob. także Ł. Młynarkiewicz, Implementacja wybranych zasad bezpieczeństwa jądrowego i ochrony radiologicznej międzynarodowej agencji energii atomowej w polskim prawie atomowym, „Studia Iuridica” 2020, 87, s. 331-353. 
niektórych standardów bezpieczeństwa MAEA (w Pr. atm. nazywanych „zaleceniami MAEA”) podczas określania wymogów w zakresie bezpieczeństwa obiektów jądrowych w rozporządzeniach ${ }^{13}$.

Kwestię organów doradczych organów dozoru jądrowego porusza kilka dokumentów MAEA z serii standardów bezpieczeństwa, kładąc duży nacisk również na konieczność zapewnienia ich niezależności. Stosownie do pkt. 4.18. GSR Part 1, który jest głównym dokumentem w zakresie rządowych, prawnych i regulacyjnych ram bezpieczeństwa jądrowego, ciała doradcze powinny dostarczać niezależnych opinii organom regulacyjnym bez względu na ich techniczny, bądź nietechniczny charakter ${ }^{14}$. Myśl tę powtarza dokument GSG-12 (pkt 4.35.), odnoszący się do kwestii organizacji organów regulacyjnych ${ }^{15}$. Ponadto GSG-12 zwraca uwagę na konieczność podległości organów doradczych najwyższym szczeblom organów regulacyjnych (pkt 4.39.) ${ }^{16}$. Niezależności organów doradczych poświęcony jest też załącznik, w całości dotyczący zewnętrznego wsparcia eksperckiego. Zgodnie z pkt. I.18. załącznika organ doradczy powinien mieć możliwość sformułowania i wyrażenia opinii technicznej opartej na kryteriach związanych z bezpieczeństwem i uwzględniającej najnowszą wiedzę naukową i techniczną oraz doświadczenie, a także powinien być bezstronny i wolny od nacisków. Organ doradczy nie powinien też być związany z żadnymi innymi organizacjami, których dotyczyć mogą wyniki jego pracy. Ponadto osąd ekspertów powinien opierać się wyłącznie na wiedzy technicznej, wynikach analiz oraz przepisach prawa i w żadnym wypadku nie powinien być stronniczy, w tym motywowany politycznie ${ }^{17}$. Zgodnie z pkt. 3.59. dokumentu GSG-13 dotyczącego funkcji organu regulacyjnego organy doradcze powinny być niezależne zarówno od podmiotów regulowanych, jaki od regulatora, i być w stanie udzielać bezstronnych opinii ${ }^{18}$. Wreszcie dokument SSG-16 dotyczący ustanawiania infrastruktury bezpieczeństwa w programie rozwoju energetyki

13 Zob. upoważnienia ustawowe do wydania rozporządzeń określających wymogi dla oceny terenu przeznaczonego pod lokalizację obiektu jądrowego, projektu obiektu jądrowego, analiz bezpieczeństwa, oceny okresowej bezpieczeństwa jądrowego, rozruchu i eksploatacji oraz likwidacji obiektu jądrowego. Zgodnie z nimi Rada Ministrów określa wymagania w ww. obszarach w rozporządzeniach "biorąc pod uwagę zalecenia Międzynarodowej Agencji Energii Atomowej wydane w tym zakresie" - zob. art. 35 b ust. $4,36 \mathrm{c}$ ust. 3,36 d ust. 3,37 e ust. $11,38,38 \mathrm{c}$ ust. 3 Pr. atm.

14 Zob. IAEA, Governmental, Legal and Regulatory Framework for Safety, IAEA Safety Standards Series, General Safety Requirements, No. GSR Part 1 (Rev. 1), Vienna 2016, s. 22.

15 Zob. IAEA, Organization, Management and Staffing of the Regulatory Body for Safety, IAEA Safety Standards Series, General Safety Guides, No. GSG-12, Vienna 2018, s. 27.

16 Ibidem, s. 28.

17 Ibidem, s. 73.

18 Zob. IAEA, Functions and Processes of the Regulatory Body for Safety, IAEA Safety Standards Series, General Safety Guides, No. GSG-13, Vienna 2018, s. 23. 
jądrowej w pkt. 2.115. zwraca uwagę na konieczność zapewnienia niezależności poszczególnych członków organu doradczego ${ }^{19}$. Konieczność zagwarantowania niezależności organom doradczym jądrowych organów regulacyjnych jest również artykułowana w innych, niż standardy bezpieczeństwa, dokumentach MAEA ${ }^{20}$ oraz w doktrynie prawa energii jądrowej ${ }^{21}$.

Przechodząc na grunt polskiego prawa administracyjnego należy zauważyć, że kwestia organów doradczych i opiniodawczych działających na rzecz centralnych organów administracji rządowej nie została kompleksowo uregulowana w przepisach prawa ani nie była dotąd przedmiotem szczególnego zainteresowania doktryny. O ile centralne organy administracji rządowej należy zaliczyć do kategorii organów decydujących (decyzyjnych), tj. załatwiających sprawy w drodze podejmowania czynności prawnych w postaci np. wydawania decyzji administracyjnych, o tyle organy opiniodawcze (doradcze) należy uznać za organy pomocnicze tworzące część aparatu pomocniczego organów decydujących. Wydając opinie i proponując działania, wykonując czynności o charakterze sprawdzająco-kontrolnym lub przygotowawczym (na wniosek bądź z własnej inicjatywy) działają one w charakterze dodatkowego, innego niż urząd obsługujący organ decyzyjny, zaplecza merytorycznego ${ }^{22}$. Kompetencje i zadania poszczególnych organów doradczych, a także kwestie ustrojowe oraz tryb ich działania są niejednolite, jako że wynikają każdorazowo z celu, dla którego (podobnie jak organy decydujące) zostały ustanowione oraz konkretyzujących go szczegółowych przepisów prawa. Wpływ na ich pozycję w krajowym porządku prawnym mogą mieć jednak normy nadrzędne, wynikające np. z przepisów wiążącego prawa międzynarodowego lub europejskiego.

Organy administracji można dzielić według różnych kryteriów. Jednym z nich jest kryterium składu osobowego. Zgodnie z nim organy administracji przyjmują formy organów jednoosobowych lub kolegialnych. W systemie polskiego prawa administracyjnego zdecydowanie dominują organy monokratyczne. Widoczne jest to zwłaszcza w odniesieniu do centralnych organów administracji rządowej spośród których zaledwie jeden na ok. 40 jest organem kolegialnym ${ }^{23}$. Obie formy

19 Zob. IAEA, Establishing the Safety Infrastructure for a Nuclear Power Programme, IAEA Safety Standards Series, Specific Safety Guides, No. SSG-16, Vienna 2011, s. 46-47.

20 Zob. IAEA, Independence in regulatory decision making. A Report by the International Nuclear Safety Advisory Group, INSAG-17, Vienna 2003, s. 13.

21 Zob. C. Stoiber, A. Baer, N. Pelzer, W. Tonhauser, Handbook on Nuclear Law, Vienna 2003, s. 32; T.R. Nowacki, Niezależność organów..., op. cit., s. 607-608.

22 Zob. J. Łukasiewicz, Zarys nauki administracji, Warszawa 2004, s. 86; [w:] J. Boć (red.), Administracja publiczna, Wrocław 2004, s. 162.

23 Mowa o Centralnej Komisji ds. Stopni i Tytułów. Oprócz niej wszystkie centralne organy administracji rządowej są organami monokratycznymi. Dotyczy to także osobliwego przypadku Urzędu Patentowego 
mają określone zalety. Preferowane w Polsce organy monokratyczne działają szybciej, w tym zdolne są do podejmowania także decyzji ad hoc oraz mają wyraźniej zlokalizowaną odpowiedzialność. Służy to niewątpliwie sprawności i elastyczności funkcjonowania aparatu administracyjnego, co ma szczególne znaczenie w obliczu znacznej ilości spraw administracyjnych, oraz wynika z potrzeb nadzoru administracyjnego. Organy kolegialne decydują wprawdzie dłużej i wolniej, ale za to odważniej, z uwagi na rozłożenie ciężaru odpowiedzialności za podjętą decyzję na większe grono osób. Równocześnie jednak uważa się, że rozstrzygnięcia organu kolegialnego są z reguły bardziej przemyślane i wyważone, podejmowane z większym uwzględnieniem kwestii społecznych oraz bardziej odporne na korupcję $e^{24}$. W tym kontekście należy zauważyć, że organy doradcze centralnych organów administracji rządowej w pewnym zakresie równoważą systemowe niedostatki monokratyczności tych ostatnich, pozwalając przynajmniej częściowo wykorzystać ww. zalety kolegialności. Choć decyzje $\mathrm{w}$ dalszym ciągu podejmowane są przez organ jednoosobowo, co również wiąże się z jednoosobową odpowiedzialnością, wnioski i opinie organu doradczego stanowiące część procesu decyzyjnego organu monokratycznego formułowane są nie tylko przez ciała spoza podstawowego aparatu pomocniczego, jakim jest urząd obsługujący dany organ, ale dodatkowo w formule kolegialnej, gdyż organ doradczy ze swej natury jest organem wieloosobowym, co znajduje odzwierciedlenie choćby w nazewnictwie (rada, komisja, komitet).

Istnienie organów doradczych przy centralnych organach administracji rządowej stanowi powszechną praktykę w polskim ustawodawstwie administracyjnym. Spośród 42 centralnych organów administracji rządowej 11 (26\%) posiada ustawowe organy doradcze ${ }^{25}$. W przypadku pozostałych organów w 24 przypadkach (57\%) możliwość utworzenia takich organów dopuszcza ustawa bądź statut. Łącznie 35 centralnych organów administracji rządowej (83\%) posiada ustawowe organy doradcze, bądź ma możliwość powołania takich organów na podstawie ustawy lub statutu. W 8 przypadkach (19\%) organ posiada zarówno ustawowy organ doradczy, jak również może taki organ powołać na podstawie statutu.

Rzeczypospolitej Polskiej, w którym to sam urząd wskazany jest jako organ. Spośród centralnych organów administracji pozarządowej do kolegialnych należą Komisja Nadzoru Finansowego i Krajowa Rada Radiofonii i Telewizji.

24 Zob. J. Boć, op. cit., s. 159-160; J. Zimmermann, Prawo administracyjne, Warszawa 2018, s. 196.

25 Liczba ta nie obejmuje Naukowej Rady Statystycznej, która jest organem działającym przy Prezesie Rady Ministrów, a nie przy Prezesie Głównego Urzędu Statystycznego. 


\section{Stan prawny sprzed nowelizacji z 2016 r.}

Rada powstała na mocy ustawy nowelizującej Pr. atm. z 2011 roku ${ }^{26}$ w celu zapewnienia wsparcia eksperckiego Prezesowi PAA ${ }^{27}$, a jej utworzenie stanowiło krok w stronę wzmocnienia niezależności tego organu. Zastąpiła ona bowiem funkcjonującą od 1982 roku Radę do Spraw Atomistyki (RdSA), której zadania i aktywność dotyczyła w znaczącej mierze promocji wykorzystania energii i energetyki jądro$w_{e j}{ }^{28}$. Istnienie Rady odpowiada międzynarodowym zaleceniom i praktyce i stanowi istotną wartość dodaną systemu nadzoru nad bezpieczeństwem wykorzystywania energii jądrowej. Rada działa przy Prezesie PAA na podstawie art. 112 ust. 2 Pr. atm. jako stały organ doradczo-opiniodawczy. Zadania Rady określone są w przepisie art. 112 ust. 8 Pr. atm. zawierającym półotwarty ich katalog. Są nimi w szczególności: 1) opiniowanie projektów zezwoleń na budowę, rozruch, eksploatację oraz likwidację obiektów jądrowych, 2) opiniowanie projektów aktów prawnych przygotowywanych przez Prezesa PAA, 3) opiniowanie projektów zaleceń organizacyjno-technicznych wydawanych przez Prezesa PAA, 4) występowanie z inicjatywami dotyczącymi usprawnienia nadzoru nad całokształtem wykonywanej działalności związanej z narażeniem na promieniowanie jonizujące ${ }^{29}$. Zastosowanie półotwartego katalogu oznacza, że zadania Rady są znacznie szersze i mogą obejmować wszelkie inne formy, jakie w opinii Prezesa PAA okażą się potrzebne w jego działalności. Szeroko należy też interpretować przepis art. 112 ust. 8 pkt 2 Pr. atm. dający Radzie uprawnienie do występowania z inicjatywami dotyczącymi usprawnienia nadzoru nad całokształtem wykonywanej działalności związanej z narażeniem na promieniowanie jonizujące. Inicjatywa ta obejmuje wszelkie działania, które w opinii Rady mogą przyczynić się do realizacji tego zadania, w tym proponowanie zmian organizacyjnych i prawnych.

26 Ustawa z dnia 13 maja 2011 r. o zmianie ustawy - Pr. atm. oraz niektórych innych ustaw (Dz. U. Nr 132, poz. 766).

27 Zob. K. Sieczak, Ustawa z dnia 29 listopada 2000 r. - Pr. atm. po nowelizacji dokonanej ustawą z dnia 13 maja 2011 r., „Bezpieczeństwo Jądrowe i Ochrona Radiologiczna” 2011, 4, s. 33.

28 Do zadań RdSA należało głównie doradztwo w zakresie rozwoju badań naukowych z zakresu atomistyki oraz technologii jądrowych, w tym energetyki jądrowej, w związku z czym była ona zarówno de iure jak i de facto podmiotem promującym zastosowania energii jądrowej. Podobny był charakter wcześniejszego organu doradczego zastąpionego przez RdSA, czyli Państwowej Rady do Spraw Pokojowego Wykorzystania Energii Jądrowej działającej w latach 1956-1982. Zob. O. Biskupski, Działalność Państwowej Rady do spraw Pokojowego Wykorzystania Energii Jądrowej, [w:] Energia jądrowa w Polsce w latach 1961-1963, Warszawa 1966, s. 7-11.

29 Zob. także szczegółowe przepisy dotyczące poszczególnych opinii Rady i terminów w jakich są przedstawiane Prezesowi PAA - art. 37b, art. 37e i art. 39f Pr. atm. 
Członkowie Rady muszą wykazywać się wiedzą i kompetencjami w zakresie prowadzonej działalności. Zgodnie z pierwotnym brzmieniem art. 112 ust. 3 Pr. atm. skład Rady wyłaniano spośród specjalistów z zakresu bezpieczeństwa jądrowego, ochrony radiologicznej, ochrony fizycznej, zabezpieczeń materiałów jądrowych oraz innych specjalności istotnych ze względu na nadzór nad bezpieczeństwem jądrowym. Członkowie Rady dodatkowo muszą posiadać poświadczenie bezpieczeństwa upoważniające do dostępu do informacji niejawnych oznaczonych klauzulą "tajne"

Członków Rady, której liczebność nie mogła przekraczać 10 osób, powoływał Prezes PAA. Wyznaczał on też jej przewodniczącego, wiceprzewodniczącego i sekretarza. Prezes PAA posiadał zatem swobodę kształtowania składu Rady ograniczoną jedynie wymogiem posiadania kompetencji oraz poświadczenia bezpieczeństwa przez osoby wchodzące w jej skład, a także ustawowo określoną maksymalną jej liczebnością. Żaden inny organ nie był uprawniony do wpływania na decyzje Prezesa PAA w tym zakresie. Odpowiadało to międzynarodowym standardom w zakresie pozycji ustrojowej jądrowych organów regulacyjnych oraz było zgodne z pragmatyką administrowania, a zwłaszcza z założeniem, że skład organu doradczego powinien kształtować organ, na rzecz którego organ doradczy działa, i który finalnie ponosi odpowiedzialność za decyzje podejmowane m.in. w oparciu o opinie organu doradczego. Kadencja Rady określona została na 4 lata, a Prezes PAA nie miał możliwości odwołania członka Rady przed upływem kadencji, co gwarantowało niezależność członków w formułowaniu swoich opinii. Obsługę Radzie zapewniał urząd obsługujący Prezesa PAA, czyli Państwowa Agencja Atomistyki. Przewodniczący Rady został zobowiązany do przekazywania Prezesowi PAA corocznego sprawozdania z działalności, które podlega niezwłocznej publikacji w Biuletynie Informacji Publicznej. Sposób i tryb pracy Rady, a także wysokość wynagrodzenia jej członków określone zostały w rozporządzeniu Ministra Środowiska z dnia 18 listopada 2011 r. w sprawie Rady do spraw Bezpieczeństwa Jądrowego i Ochrony Radiologicznej30.

\section{Istota nowelizacji}

Nowelizacja z 2016 r. przeniosła kompetencje do powoływania członków Rady z Prezesa PAA na nadzorującego ministra ${ }^{31}$, wprowadziła możliwość dyskrecjonalnego odwołania członków Rady przez tegoż ministra, rozszerzyła grono specjalistów

30 Dz. U. Nr 279, poz. 1643.

31 Wówczas był nim minister właściwy ds. środowiska. Obecnie jest to minister właściwy ds. klimatu. 
spośród których powołuje się członków Rady o specjalistów geochemii pierwiastków promieniotwórczych i specjalistów w zakresie składowania materiałów jądrowych, ustaliła katalog przyczyn ustania członkostwa w Radzie oraz wygaszała kadencję Rady powołanej na mocy zmienianych przepisów ${ }^{32}$.

Zgodnie z nowym brzmieniem art. 112 ust. 3 Pr. atm. minister właściwy ds. środowiska zyskał kompetencje do powoływania członków Rady, a na mocy nowo wprowadzonego ust. 3a w tym artykule także do wyznaczania spośród jej składu przewodniczącego, wiceprzewodniczącego oraz sekretarza. Tym samym odebrano te kompetencje Prezesowi PAA, który korzystał z nich przez ponad 30 lat ${ }^{33}$. Przy powołaniu konieczne jest wprawdzie zaopiniowanie kandydatury przez Prezesa PAA, pozostaje to jednak bez wpływu na swobodę działania ministra, gdyż opinia ta nie ma wiążącego charakteru. Przyczyn tej zmiany na próżno szukać w uzasadnieniu do (poselskiego) projektu ustawy, które jest więcej niż lakoniczne. Stwierdza ono jedynie, że „Jednocześnie proponuje się modyfikację trybu powoływania Rady poprzez uwzględnienie roli ministra właściwego do spraw środowiska, który stosownie do art. 28 ust. 3 ustawy z dnia 4 września 1997 r. o działach administracji rządowej (...) nadzoruje Prezesa Państwowej Agencji Atomistyki." ${ }^{34}$. Podobnie enigmatyczne są wyjaśnienia przedstawiciela formalnego wnioskodawcy (grupy posłów), który w trakcie posiedzenia sejmowej Komisji Ochrony Środowiska, Zasobów Naturalnych i Leśnictwa stwierdził jedynie, że celem projektowanej zmiany jest „(...) uporządkowanie rozwiązań dotyczących Rady do spraw Bezpieczeństwa Jądrowego i Ochrony Radiologicznej.”, w tym „(...) uporządkowanie kwestii dotyczących chociażby możliwości zasiadania, lub też nie, w tejże radzie." Dodatkowo wskazał on, że projektowane rozwiązanie daje „(...) możliwość ministrowi właściwemu do spraw środowiska, aby wskazywał spośród członków rady przewodniczącego rady, zastępcę oraz sekretarza tejże rady"35. Wypowiedź ta została powtórzona podczas drugiego czytania na posiedzeniu Sejmu ${ }^{36}$.

32 Por. krótkie omówienie nowelizacji w „Nuclear Law Bulletin” 2016, 2, s. 78-79. W materiale tym zwracano uwagę na ograniczenie autonomii Prezesa PAA, a w odniesieniu do zmian dotyczących Rady wskazano, że de facto przestała być ona organem Prezesa PAA a stała się organem nadzorującego ministra doradzającym Prezesowi PAA. Zob. także całościową analizę krytyczną nowelizacji Pr. atm. z 2016 r.: T.R. Nowacki, Ograniczenie..., op. cit., s. 53-73.

33 Od 2011 w odniesieniu do Rady, a w latach 1982 - 2011 w odniesieniu do Rady do Spraw Atomistyki.

34 Uzasadnienie do projektu ustawy o zmianie ustawy - Prawo atomowe, Druk sejmowy nr 570 Sejmu IX kadencji, s. 1 (brak paginacji).

35 Kancelaria Sejmu, Biuro Komisji Sejmowych, Petny zapis przebiegu posiedzenia Komisji Ochrony Środowiska, Zasobów Naturalnych i Leśnictwa (nr 28) z dnia 21 czerwca 2016 r., s. 3, http://orka.sejm.gov.pl/zapisy8.nsf/0/ C211B06F2E538AE6C1257FDC004789C7/\%24File/0074308.pdf (dostęp: 28.04.2020).

36 Zob. Sejm Rzeczypospolitej Polskiej, Kadencja VIII, Sprawozdanie Stenograficzne z 22. posiedzenia Sejmu Rzeczypospolitej Polskiej w dniu 5 lipca 2016 r. (pierwszy dzień obrad), Warszawa 2016, s. 89. 
Więcej światła na motywy autorów projektu ustawy wydają się rzucać opinie wyrażane przez przedstawicieli Rady Ministrów w trakcie całego postępowania ustawodawczego w Sejmie i Senacie, choć formalnie to nie Rada Ministrów była wnioskodawcą. Podczas prac w komisji sejmowej przedstawiciel Rady Ministrów stwierdzil, że zmiana stanu prawnego pozwoli na zniesienie konfliktu interesów polegającego rzekomo na tym, że niektórzy członkowie Rady zatrudnieni są w jednostkach organizacyjnych, które podlegają działalności regulacyjnej ze strony Prezesa PAA, a więc organu, któremu doradzają ${ }^{37}$. W podobnym duchu, na posiedzeniu plenarnym Sejmu, wypowiadał się inny przedstawiciel Rady Ministrów, dodając, że fakt powoływania członków Rady przez Prezesa PAA wyklucza możliwość ich niezależności w opiniowaniu działalności tegoż organu. Wskazywał on także, bez podawania przyczyn, na konieczność wzmocnienia nadzoru nad Prezesem PAA ze strony ministra przez przejęcie kompetencji w zakresie powoływania członków Rady oraz podnosił, że kształtowanie składu Rady przez ministra sprawi, że będzie to ciało politycznie neutralne (sic! ${ }^{38}$. Na posiedzeniu Senatu przedstawiciel Rady Ministrów twierdził zaś wbrew obowiązującym wówczas przepisom, że Rada jest organem ministra i że powinien on móc powoływać ludzi, do których ma zaufanie. Podnosił też, że wprowadzana zmiana stanowi ujednolicenie przepisów w zakresie powoływania członków organów doradczych, gdyż jest rozwiązaniem analogicznym do zastosowanego $\mathrm{w}$ przypadku powoływania organu doradczego innego centralnego organu administracji rządowej, tj. Generalnego Dyrektora Ochrony Środowiska (GDOŚ) ${ }^{39}$. Stwierdzenie to nie miało jednak oparcia w przepisach prawa, gdyż skład tego organu (Krajowa Komisja Ocen Oddziaływania na Środowisko) ustalał, i ustala obecnie, GDOŚ ${ }^{40}$.

Przepis art. 112 ust. 5a Pr. atm. określił katalog przyczyn ustania członkostwa w Radzie, czego dotychczasowa regulacja nie przewidywała. Obok pisemnej

37 Zob. wypowiedź ówczesnego pełniącego obowiązki Prezesa PAA, ibidem, s. 4. Należy w tym miejscu zauważyć, że jest to argument zupełnie nietrafiony. Zgodnie z przepisami istnieje obowiązek wyłączenia się takich członków z głosowania stosownie do $§ 6$ ust. 5 ww. rozporządzenia ws. Rady (zob. przypis 29).

38 Zob. wypowiedź ówczesnego sekretarza stanu w Ministerstwie Środowiska, który w imieniu Ministra Środowiska sprawował nadzór nad Prezesem PAA, Sejm Rzeczypospolitej Polskiej, Kadencja VIII, Sprawozdanie Stenograficzne z 22. posiedzenia Sejmu Rzeczypospolitej Polskiej w dniu 5 lipca 2016 r. (pierwszy dzień obrad), Warszawa 2016, s. 92.

39 Zob. Senat Rzeczypospolitej Polskiej, IX kadencja, Sprawozdanie Stenograficzne z 24. posiedzenia Senatu Rzeczypospolitej Polskiej w dniach 3 i 4 sierpnia 2016 r., Warszawa 2016, s. 66-67.

40 Zob. art. 132 ust. 2 ustawy z dnia 3 października 2008 r. o udostępnianiu informacji o środowisku i jego ochronie, udziale społeczeństwa w ochronie środowiska oraz o ocenach oddziaływania na środowisko (Dz. U. z 2020 r., poz. 283 ze zm.). Przepis ten zachowuje pierwotne brzmienie, aktualne również w trakcie omawianych prac parlamentarnych. 
rezygnacji członka rady oraz jego śmierci - przyczyn oczywistych w przypadku organu kadencyjnego, wprowadzono także możliwość odwołania członka Rady. Norma kompetencyjna w tym zakresie znajduje się w przepisie art. 112 ust. 3 Pr. atm. w nowym brzmieniu. Do odwołania członka Rady upoważnia ona, analogicznie jak ma to miejsce przy powołaniu, nadzorującego ministra. Norma kompetencyjna nie zawiera żadnych ograniczeń tego uprawnienia, nie ma go też w innych przepisach Pr. atm., co oznacza, że do odwołania członka rady nie jest konieczne podawanie przyczyn dokonania tej czynności. Wprowadzona możliwość jest dyskrecjonalnym uprawnieniem ministra. W rezultacie ustanie członkostwa w Radzie może nastąpić wbrew woli członka w trakcie pełnionej kadencji. Uzasadnienie projektu ustawy, choć mówi o konieczności uzupełnienia uregulowań ustawowych o możliwość odwołania członków Rady, milczy na temat powodów przyjętego rozwiązania $^{41}$. Analogiczne w treści były wypowiedzi przedstawiciela wnioskodawcy. Wskazano tylko na konieczność takiego uregulowania bez podawania przyczyn ${ }^{42}$.

Nowy przepis art. 112 ust. 3 Pr. atm. zwiększył ilość specjalności, jakimi legitymować się mają członkowie Rady. Do tej pory były to: bezpieczeństwo jądrowe, ochrona radiologiczna, ochrona fizyczna, zabezpieczenie materiałów jądrowych. Ustawa dopuszczała także możliwość powołania specjalistów „spośród innych specjalności istotnych ze względu na nadzór nad bezpieczeństwem jądrowym i ochroną radiologiczną", co nadawało wyliczeniu charakter katalogu półotwartego, umożliwiającego elastyczną selekcję członków Rady. Takie podejście należy uznać za zasadne. Regulacja działalności z wykorzystaniem obiektów jądrowych jest procesem złożonym i wieloaspektowym, tak jak złożona i wieloaspektowa jest np. budowa elektrowni jądrowej, lub choćby reaktora badawczego. Oprócz czterech newralgicznych obszarów bezpośrednio wymienionych w przepisach ustawy może okazać się konieczne pozyskanie specjalistów z innych dziedzin, jak np. budownictwo, instalacje elektryczne, geologia inżynierska, geotechnika, informatyka, cyberbezpieczeństwo. Mimo istnienia tej swoistej klauzuli generalnej zdecydowano się na dodanie do wyliczenia nowych specjalności: geochemii pierwiastków promieniotwórczych oraz składowania materiałów jądrowych. Ani w uzasadnieniu do projektu ustawy, ani w wystąpieniach wnioskodawców i przedstawicieli Rady Ministrów nie podano powodów tej zmiany.

41 Zob. Uzasadnienie do projektu ustawy o zmianie ustawy - Prawo atomowe, Druk sejmowy nr 570 Sejmu IX kadencji, s. 1 (brak paginacji).

42 Zob. Kancelaria Sejmu, Biuro Komisji Sejmowych, Petny zapis przebiegu posiedzenia Komisji Ochrony Środowiska, Zasobów Naturalnych i Leśnictwa (nr 28) z dnia 21 czerwca 2016 r., s. 3, http://orka.sejm.gov.pl/ zapisy8.nsf/0/C211B06F2E538AE6C1257FDC004789C7/\%24File/0074308.pdf (dostęp: 28.04.2020); Sejm Rzeczypospolitej Polskiej, Kadencja VIII, Sprawozdanie Stenograficzne z 22. posiedzenia Sejmu Rzeczypospolitej Polskiej w dniu 5 lipca 2016 r. (pierwszy dzień obrad), Warszawa 2016, s. 89. 


\section{Krytyka zmian}

Zmiany dokonane w Pr. atm. nowelizacją z 2016 r. należy w zdecydowanej większości ocenić negatywnie. Przede wszystkim negatywnie należy ocenić odebranie Prezesowi PAA, jako naczelnemu organowi dozoru jądrowego (stosownie do art. 64 ust. 1 pkt 1 Pr. atm.), uprawnienia do kształtowania składu Rady. Przy powołaniu konieczne jest wprawdzie zaopiniowanie kandydatury członka Rady przez Prezesa PAA. Pozostaje to jednak bez faktycznego wpływu na działania ministra, który zachowuje swobodę decyzyjną, gdyż opinia ta nie ma wiążącego charakteru. Nowe rozwiązanie nie tylko zatem odbiera Prezesowi PAA możliwość wyboru członków Rady, ale też nie daje mu możliwości zablokowania niepożądanej kandydatury. Pozbawienie Prezesa PAA uprawnień posiadanych przez niego przez ponad 30 lat $^{43}$, mocno osadzonych w praktyce i tradycji systemu nadzoru nad wykorzystywaniem energii jądrowej i promieniowania jonizującego w Polsce, stanowi regres $\mathrm{w}$ stosunku do dotychczasowych uregulowań $\mathrm{i}$ tendencji ustawodawczych $\mathrm{z}$ ostatnich lat $\mathrm{w}$ tym zakresie. Stanowi to także zaprzeczenie istoty Rady jako organu doradczego centralnego organu administracji rządowej. W opinii autora to wyspecjalizowany organ decydujący powinien kształtować skład swojego organu doradczego, który pełni przecież wobec niego rolę służebną. Organ ten jako jedyny ponosi odpowiedzialność za podjęte rozstrzygnięcia, $w$ tym wydane decyzje administracyjne, które podejmowane są m.in. w oparciu o stanowisko organu doradczego, a co za tym idzie, to on powinien określać skład organów doradczych. Dotyczy to w szczególności przypadku Prezesa PAA, gdyż jednym z głównych zadań Rady jest właśnie opiniowanie projektów decyzji administracyjnych, tj. zezwoleń na budowę, rozruch, eksploatację oraz likwidację obiektów jądrowych. Równolegle do faktu ponoszenia przez Prezesa PAA odpowiedzialności za podejmowane decyzje należy wskazać także na fakt, iż to ten organ, z uwagi na swoją specjalizację, ma największe spośród organów państwowych doświadczenie i wiedzę w zakresie bezpieczeństwa jądrowego i ochrony radiologicznej oraz potrzeb w zakresie regulacji tego sektora. Dzięki temu może on dokonać optymalnego wyboru kandydatów i ocenić ich przydatność dla swojej działalności. Taka wiedza nie jest dostępna żadnemu innemu organowi państwowemu ${ }^{44}$.

Ustalanie składu organu doradczego przez inny organ stanowi też pośrednią ingerencję w niezależność Prezesa PAA jako organu dozoru jądrowego, zarówno $\mathrm{w}$ wymiarze zakreślonym prawem międzynarodowym i europejskim, jak i regulacjami krajowymi. Obowiązek zapewnienia niezależności organom dozoru jądrowego

43 Wcześniej w odniesieniu do RdSA.

44 Zob. T.R. Nowacki, Ograniczenie..., op. cit., s. 67-68. 
mający swe źródła we wspomnianych wyżej aktach prawa międzynarodowego i europejskiego ${ }^{45}$ rozciąga się na cały proces decyzyjny. Częścią tego procesu w Polsce jest m.in. opiniowanie projektów decyzji administracyjnych Prezesa PAA przez Radę. Trudno uznać za w pełni niezależną, w rozumieniu przepisów prawa międzynarodowego i europejskiego, opinię organu doradczego, którego skład określa organ inny niż organ decydujący oraz którego członkowie nie mają zagwarantowanej niezależności personalnej w postaci np. gwarancji kadencyjności. Na gruncie prawa krajowego obecny stan prawny oznaczać może także pośrednie naruszenie art. 34a ust. 2 ustawy z dnia 8 sierpnia 1996 r. o Radzie Ministrów ${ }^{46}$. Stosownie do tego przepisu minister nie może wpływać na rozstrzygnięcia co do istoty sprawy załatwianej w drodze decyzji administracyjnej przez nadzorowany przez niego organ. Wyznaczanie przez ministra członków Rady (w połączeniu z wyznaczeniem jej przewodniczącego, wiceprzewodniczącego i sekretarza) z jednoczesną możliwością ich odwołania bez podania przyczyn oznaczać może usankcjonowanie pośredniego wpływu ministra na rozstrzygnięcia administracyjne Prezesa PAA w odniesieniu do obiektów jądrowych.

Negatywnie należy ocenić również wprowadzenie możliwości odwołania członków Rady bez podania przyczyn, a tym samym zakończenia ich misji przed końcem kadencji nawet wbrew ich woli. Taki stan rzeczy narusza wprost niezależność Rady, gdyż jej członkowie nie mają żadnej gwarancji, że nie zostaną odwołani za prezentowanie poglądów niezgodnych $\mathrm{z}$ wizją ministra nadzorującego Prezesa PAA, bądź samego Prezesa PAA. Całkowicie niweczy to cel powstania Rady, która w założeniu swoje opinie opierać ma jedynie na eksperckiej wiedzy swoich członków kierujących się jedynie przesłanką zapewnienia bezpieczeństwa (zasada safety first). Możliwość dyskrecjonalnego odwołania członków Rady przed upływem kadencji daje ministrowi nadzorującemu zupełną dowolność kształtowania składu Rady, co przekłada się również na pośrednią możliwość wpływania na rozstrzygnięcia Rady w drodze działań nieformalnych. W przypadku braku gwarancji stałości członkostwa w Radzie na okres kadencji członkowie tego gremium mogą być podatni na naciski poparte groźbą utraty stanowiska w przypadku podejmowania działań niezgodnych z wizją nadzorującego ministra.

Krytycznie należy ocenić także zmianę w postaci powiększenia ilości specjalizacji członków Rady. Trudno wyjaśnić, dlaczego wśród tych specjalności znalazła się geochemia pierwiastków promieniotwórczych, a więc specjalność niszowa i nieistotna z punktu widzenia regulacji działalności z wykorzystaniem obiektów jądrowych, tj. głównego obszaru aktywności Rady. Dotychczasowy przepis art. 112

$45 \quad$ Zob. przypisy 5 i 6.

46 Dz. U. z 2019 r., poz. 1171 ze zm. 
ust. 3 Pr. atm. zawierał cztery podstawowe kategorie specjalności istotne dla wykonywania działań Rady oraz generalną klauzulę pozwalającą na dołączenie do składu Rady specjalistów z innych dziedzin, które są istotne ze względu na nadzór nad bezpieczeństwem jądrowym i ochroną radiologiczną. Jeśliby więc geochemia pierwiastków promieniotwórczych okazała się specjalnością istotną, to osobę legitymującą się doświadczeniem $\mathrm{w}$ tej dziedzinie i tak można by było powołać. Wiele wskazuje jednak na to, że wnioskodawca uznał, iż specjalność ta nie wchodzi w zakres klauzuli generalnej i że z jakiegoś powodu trzeba dopisać ją do wyliczenia. Jeszcze mniej zrozumiałe jest dodanie do wyliczenia słowa „składowania". W obecnym brzmieniu art. 112 ust. 3 Pr. atm. oznacza, że członkami rady mogą być również specjaliści w zakresie składowania materiałów jądrowych. Tymczasem materiały jądrowe ${ }^{47}$ to tylko niewielka część podlegających składowaniu odpadów promieniotwórczych. Pod względem technicznym nie ma różnicy w składowaniu odpadów promieniotwórczych zawierających lub nie materiały jądrowe. Również prawne zasady składowania odpadów promieniotwórczych zawierających materiały jądrowe nie różnią się od ogólnych zasad składowania odpadów promieniotwórczych określonych w rozdziale 7 Pr. atm., z wyjątkiem dodatkowego obowiązku ochrony fizycznej i zabezpieczeń materiałów jądrowych ${ }^{48}$. Nie ma zatem logicznej przesłanki uzasadniającej wyróżnienie specjalizacji w zakresie składowania materiałów jądrowych w wyliczeniu w art. 112 ust. 3 Pr. atm. Z dużym prawdopodobieństwem można założyć, iż wprowadzona zmiana jest wynikiem błędu legislacyjnego popełnionego przez wnioskodawcę już na etapie sporządzania projektu ustawy.

Niezależnie od uwag w odniesieniu do poszczególnych przepisów krytycznie należy ocenić również niektóre aspekty formalne nowelizacji. Przede wszystkim należy wskazać na niedostatki w zakresie uzasadnienia projektu. Stosownie do art. 34 ust. 2 Regulaminu Sejmu ${ }^{49}$ do projektu ustawy dołącza się uzasadnienie, które m.in. ma wyjaśniać potrzebę i cel wydania ustawy, przedstawiać rzeczywisty stan w dziedzinie, która ma być unormowana, wykazywać różnicę pomiędzy dotychczasowym a projektowanym stanem prawnym, przedstawiać przewidywane skutki społeczne, gospodarcze, finansowe i prawne. Dołączone do projektu uzasadnienie (o objętości niecałej strony) w szczególności nie wyjaśniało w ogóle potrzeby

47 Zob. definicję legalną w art. 3 pkt 11 Pr. atm. oraz art. 197 Traktatu ustanawiającego Europejską Wspólnotę Energii Atomowej sporządzonego w Rzymie 25 marca 1957 r. (Traktat Euratom - Skonsolidowana wersja polskojęzyczna Dz. Urz. UE C 84 z 30.3.2010). Por. także art. 40 pkt 4 b i 8a Pr. atm.

48 Zob. art. 41e i art. 49b Pr. atm.

49 Uchwała Sejmu Rzeczypospolitej Polskiej z dnia 30 lipca 1992 r. - Regulamin Sejmu Rzeczypospolitej (M.P. z 2019 r., poz. 1028 ze zm.). Brzmienie art. 34 obowiązujące na dzień wniesienia projektu nie uległo zmianie. Por. ówczesną wersję regulaminu (M.P. z 2012 r., poz. 32 ze zm.). 
i celu zmian przepisów w zakresie Rady. W sposób niezwykle lakoniczny jedynie opisywało projektowaną zmianę. Dodatkowo w ogóle nie przedstawiało skutków prawnych planowanej zmiany, przemilczając zwłaszcza negatywne skutki ubezwłasnowolnienia niezależnego do tej pory organu doradczego. Odnotować należy także fakt, iż na etapie prac w komisji Senatu nie był obecny ani upoważniony przedstawiciel wnioskodawcy, ani poseł sprawozdawca, choć zgodnie z art. 68 ust. $1 \mathrm{~b}$ Regulaminu Senatu ${ }^{50}$ są oni każdorazowo zapraszani na posiedzenie komisji rozpatrującej ustawę.

Kończąc krytyczną analizę przedmiotowej nowelizacji, nie można nie odnieść się do trybu ustawodawczego, jaki był zastosowany. Projekt ustawy od strony formalnej był projektem poselskim, jednak wiele wskazuje no to, że w istocie był to projekt, który powstał w jednym z ministerstw, i dla którego jedynie wykorzystano inicjatywę ustawodawczą grupy posłów celem uproszczenia i skrócenia procedury legislacyjnej. Przesłanek świadczących o słuszności takiego rozumowania jest kilka. Po pierwsze trudno przypuszczać, że tryb obsady stanowisk w organie doradczym jednego z mniej rozpoznawalnych centralnych organów administracji rządowej stanowi przedmiot zainteresowania przedstawicieli suwerena w Sejmie. Po drugie, jak wynika z przebiegu prac legislacyjnych w Sejmie i Senacie, projekt prezentowali faktycznie przedstawiciele Rady Ministrów. Po trzecie należy zadać typowe w takiej sytuacji pytanie - cui bono? Jedyną wyraźną korzyść z nowej regulacji odnosił minister nadzorujący wówczas Prezesa PAA (względnie sekretarz stanu wykonujący uprawnienia ministra $w$ tym zakresie), ponieważ mógł on przejąć uprawnienie do obsadzania stanowisk, równocześnie zapewniając sobie pełną swobodę ksztaltowania składu Rady, której nie miał nawet Prezes PAA, poprzez wprowadzenie (nieograniczonej) możliwości odwołania członków Rady w trakcie trwania kadencji bez podania przyczyn ${ }^{51}$. Wykorzystywanie poselskiej inicjatywy ustawodawczej dla projektów, które powstają w łonie Rady Ministrów, należy ocenić negatywnie. Znacząco ogranicza to udział społeczeństwa w procesie legislacyjnym (projekty rządowe poddaje się konsultacjom publicznym i opiniowaniu), a także wiąże się

50 Uchwała Senatu Rzeczypospolitej Polskiej z dnia 23 listopada 1990 r. - Regulamin Senatu (M.P. z 2018 r., poz. 846 ze zm.). Brzmienie art. 68 obowiązujące na dzień rozpatrywania ustawy nie uległo zmianie. Por. ówczesną wersję regulaminu (M.P. z 2015 r., poz. 805 ze zm.).

51 Zob. także zapisy posiedzeń Sejmu i Senatu, gdzie w opinii niektórych posłów i senatorów taki był właśnie prawdziwy cel nowelizacji. Sejm Rzeczypospolitej Polskiej, Kadencja VIII, Sprawozdanie Stenograficzne z 22. posiedzenia Sejmu Rzeczypospolitej Polskiej w dniu 5 lipca 2016 r. (pierwszy dzień obrad), Warszawa 2016, s. 89; idem, Sprawozdanie Stenograficzne z 22. posiedzenia Sejmu Rzeczypospolitej Polskiej w dniu 6 lipca 2016 r. (drugi dzień obrad), Warszawa 2016, s. 287; Senat Rzeczypospolitej Polskiej, IX kadencja, Sprawozdanie Stenograficzne z 24. posiedzenia Senatu Rzeczypospolitej Polskiej w dniach 3 i 4 sierpnia 2016 r., Warszawa 2016, s. 66-67. 
z redukcją czynnika merytorycznego, który z uwagi na zaplecze analityczne i eksperckie jest silniej reprezentowany w Radzie Ministrów.

\section{Podsumowanie}

Nowelizacja Pr. atm. z 2016 r. odebrała Prezesowi PAA kompetencje w zakresie kształtowania składu Rady. Od tego momentu członków Rady powołuje minister nadzorujący Prezesa PAA (najpierw minister właściwy ds. środowiska, a następnie od 2020 r. minister właściwy ds. klimatu). Co więcej, wprowadzono możliwość odwołania członków Rady, w dodatku bez określenia przesłanek tegoż odwołania, co oznaczało, że minister uzyskał uprawnienie do dyskrecjonalnego kształtowania wedle własnej woli składu Rady. Nowy stan prawny stanowi niewątpliwie krok wstecz w stosunku do poprzednio obowiązujących rozwiązań i powinien być odczytywany jako idący wbrew ratio legis utworzenia Rady w 2011 roku. Nie tylko pozbawiono centralny organ administracji rządowej wpływu na kształtowanie składu swojego organu doradczego, a więc uprawnienia posiadanego przez ponad 30 lat, ale wprowadzając możliwość odwołania członków w trakcie kadencji bez podania przyczyn, de facto zlikwidowano niezależność tego organu. Nowy stan prawny oznacza, iż istnieje możliwość pozamerytorycznego wpływania na rozstrzygnięcia Rady, np. w drodze presji na jej członków związanej z możliwością utraty w każdej chwili piastowanego stanowiska. Z uwagi na powyższe, dla zapewnienia prawidłowego przebiegu procesu regulacyjnego w zakresie bezpieczeństwa jądrowego i ochrony radiologicznej w Polsce, z poszanowaniem obowiązku zapewnienia niezależności organów dozoru jądrowego, należy przywrócić pozycję ustrojową Rady sprzed nowelizacji Pr. atm. z 2016 r. Członków Rady powinien na powrót powoływać Prezes PAA, a możliwość odwołania członków w trakcie pełnienia kadencji bez podania przyczyn powinna zostać zniesiona. Należy też zrezygnować z zastosowanego rozszerzenia listy specjalności członków Rady, jako rozwiązania bez uzasadnienia i widocznych korzyści. Specjaliści z geochemii nie są istotni dla procesu regulacyjnego obiektów jądrowych, a składowanie materiałów jądrowych nie istnieje jako samodzielna dziedzina. Przywrócenie poprzednich zasad kształtowania składu Rady poprawi efektywność jej działania i pozytywnie wpłynie na przebieg procesu regulacyjnego w działalności z wykorzystaniem energii jądrowej i promieniowania jonizującego. Należy również zakładać, że redukcja czynnika politycznego, jakim jest powoływanie i odwoływanie członków Rady przez ministra, na rzecz przywrócenia czynnika merytorycznego i eksperckiego pozytywnie wpłynie na poziom zaufania społecznego do organów dozoru jądrowego. Ma to 
szczególne znaczenie w kontekście rządowych planów budowy elektrowni jądrowych w Polsce.

\section{Bibliografia}

\section{Literatura}

Biskupski O., Dziatalność Państwowej Rady do spraw Pokojowego Wykorzystania Energii Jądrowej, [w:] Energia jądrowa w Polsce w latach 1961-1963, Warszawa 1966.

Boć J. (red.), Administracja publiczna, Wrocław 2004.

Dworak W., Podstawy instytucjonalne konieczne do rozwoju energetyki jądrowej w Polsce, „Rocznik Nauk Prawnych” 2014, 2.

Firlus J.G., Michalak K., Realizacja inwestycji w zakresie budowy obiektu jądrowego w Polsce - wybrane zagadnienia, „Przegląd Prawa Publicznego” 2015, 9.

Łukasiewicz J., Zarys nauki administracji, Warszawa 2004.

Młynarkiewicz Ł., Implementacja wybranych zasad bezpieczeństwa jądrowego i ochrony radiologicznej Międzynarodowej Agencji Energii Atomowej w polskim Prawie atomowym, „Studia Iuridica” 2020, 87.

National legislative and regulatory activities. Poland. Organisation and structure, "Nuclear Law Bulletin" 2016, 2.

Nowacki T.R., Możliwość uznania standardów bezpieczeństwa Międzynarodowej Agencji Energii Atomowej za źródło prawa w świetle Konstytucji Rzeczypospolitej Polskiej, [w:] H. Babiuch, P. Kapusta, J. Michalska (red.), Aktualne problemy konstytucji. Księga jubileuszowa z okazji 40-lecia pracy naukowej Profesora Bogustawa Banaszaka, Legnica 2017.

Nowacki T.R., Niezależność organów dozoru jądrowego. Próba rekonstrukcji zakresu pojęciowego, [w:] K. Jeleń, Z. Rau (red.), Energetyka jadrowa w Polsce, Warszawa 2012.

Nowacki T.R., Ograniczenie autonomii Prezesa Państwowej Agencji Atomistyki, „Przegląd Sejmowy" 2018, 4.

Nowacki T.R., Prawne gwarancje niezależności dozoru jądrowego w Polsce, [w:] I. Ramus (red.), Obrót powszechny i gospodarczy. Problemy publicznoprawne i ekonomiczne, Kielce 2014.

Stoiber C., Baer A., Pelzer N., Tonhauser W., Handbook on Nuclear Law, Vienna 2003.

Stoiber C., Cherf A., Tonhauser W., de Loudres Vez Carmona M., Handbook on Nuclear Law. Implementing Legislation, Vienna 2010.

Sieczak K., Ustawa z dnia 29 listopada 2000 r. - Prawo atomowe po nowelizacji dokonanej ustawa z dnia 13 maja 2011 r., „Bezpieczeństwo Jądrowe i Ochrona Radiologiczna” 2011, 4 .

Tokarz G., Rada do spraw bezpieczeństwa jadrowego i ochrony radiologicznej-geneza, usytuowanie, dziatalność, [w:] P. Kwiatkiewicz, R. Szczerbowski (red.), Bezpieczeństwo ener- 
getyczne: rynki surowców i energii: energetyka w czasach politycznej niestabilności. Bezpieczeństwo, gospodarka, ochrona środowiska, polityka, technologia, zarządzanie, Poznań 2015.

Tokarz G. [w:] R. Szczerbowski (red.), Energetyka węglowa i jądrowa: wybrane aspekty, Poznań 2017.

Tokarz G. [w:] R. Maciejewski (red.), Cyberbezpieczeństwo i bezpieczeństwo fizyczne obiektów w energetyce: wybrane aspekty badawcze, Poznań 2018.

Tokarz G., Bezpieczeństwo jądrowe i ochrona radiologiczna. Nie tylko PAA..., „Energia Gigawat" 2016, 1.

Walker J.S., Wellock T.R., A Short History of Nuclear Regulation 1946-2009, Washington 2010.

Zimmermann J., Prawo administracyjne, Warszawa 2018.

\section{Źródła}

IAEA, Establishing the Safety Infrastructure for a Nuclear Power Programme, IAEA Safety Standards Series, Specific Safety Guides, No. SSG-16, Vienna 2011.

IAEA, Functions and Processes of the Regulatory Body for Safety, IAEA Safety Standards Series, General Safety Guides, No. GSG-13, Vienna 2018.

IAEA, Governmental, Legal and Regulatory Framework for Safety, IAEA Safety Standards Series, General Safety Requirements, No. GSR Part 1 (Rev. 1), Vienna 2016.

IAEA, Independence in regulatory decision making. A Report by the International Nuclear Safety Advisory Group, INSAG-17, Vienna 2003.

IAEA, Organization, Management and Staffing of the Regulatory Body for Safety, IAEA Safety Standards Series, General Safety Guides, No. GSG-12, Vienna 2018.

Kancelaria Sejmu, Biuro Komisji Sejmowych, Petny zapis przebiegu posiedzenia Komisji Ochrony Środowiska, Zasobów Naturalnych i Leśnictwa (nr 28) z dnia 21 czerwca 2016 r., http://orka.sejm.gov.pl/zapisy8.nsf/0/C211B06F2E538AE6C1257FDC004789C7/\%24File/0074308.pdf (dostęp: 28.04.2020).

Sejm Rzeczypospolitej Polskiej, Kadencja VIII, Sprawozdanie Stenograficzne z 22. posiedzenia Sejmu Rzeczypospolitej Polskiej w dniu 5 lipca 2016 r. (pierwszy dzień obrad), Warszawa 2016.

Sejm Rzeczypospolitej Polskiej, Kadencja VIII,, Sprawozdanie Stenograficzne z 22. posiedzenia Sejmu Rzeczypospolitej Polskiej w dniu 6 lipca 2016 r. (drugi dzień obrad), Warszawa 2016.

Senat Rzeczypospolitej Polskiej, IX kadencja, Sprawozdanie Stenograficzne z 24. posiedzenia Senatu Rzeczypospolitej Polskiej w dniach 3 i 4 sierpnia 2016 r., Warszawa 2016.

Uzasadnienie do projektu ustawy o zmianie ustawy - Prawo atomowe, Druk sejmowy nr 570 Sejmu IX kadencji. 